\title{
Homeostatic and toxic mechanisms regulating manganese uptake, retention, and elimination
}

\author{
JEROME A ROTH
}

Department of Pharmacology and Toxicology, University at Buffalo, Buffalo, New York, USA

\begin{abstract}
This review attempts to summarize and clarify our basic knowledge as to the various factors that potentially influence the risks imposed from chronic exposure to high atmospheric levels of manganese (Mn). The studies describe the interrelationship of the different systems in the body that regulate Mn homeostasis by characterizing specific, biological components involved in its systemic and cellular uptake and its elimination from the body. A syndrome known as manganism occurs when individuals are exposed chronically to high levels of Mn, consisting of reduced response speed, intellectual deficits, mood changes, and compulsive behaviors in the initial stages of the disorder to more prominent and irreversible extrapyramidal dysfunction resembling Parkinson's disease upon protracted exposure. Mn intoxication is most often associated with occupations in which abnormally high atmospheric concentrations prevail, such as in welding and mining. There are three potentially important routes by which $\mathrm{Mn}$ in inspired air can gain access the body to: 1) direct uptake into the CNS via uptake into the olfactory or trigeminal presynaptic nerve endings located in the nasal mucosa and the subsequent retrograde axonal transport directly into the CNS; 2) transport across the pulmonary epithelial lining and its subsequent deposition into lymph or blood; and/or 3) mucocilliary elevator clearance from the lung and the subsequent ingestion of the metal in the gastrointestinal tract. Each of these processes and their overall contribution to the uptake of $\mathrm{Mn}$ in the body is discussed in this review as well as a description of the various mechanisms that have been proposed for the transport of Mn across the bloodbrain barrier which include both a transferrin-dependent and a transferrin-independent process that may involve store-operated $\mathrm{Ca}$ channels.
\end{abstract}

Key terms: manganese, iron, lung, Parkinson's disease, divalent metal transporter (DMT1), transferrin, transferrin receptor

Manganese $(\mathrm{Mn})$ is one of the most prevalent metals on the earth, being the fifth most abundant metal and twelfth most abundant element on earth. It is an essential component for the production of steel, batteries, welding metals, ceramics, and pigments. In nature, $\mathrm{Mn}$ exists in 11 different oxidation states ranging from -3 to +7 , although within biological systems the +2 and +3 valences are the most dominant species. Within recent years, the U.S. has developed considerable interest in $\mathrm{Mn}$ because of the potential health risk associated with increased atmospheric levels prompted by the impending use of the gas additive methylcyclopentadienyl manganese tricarbonyl (MMT).
$\mathrm{Mn}$ is an essential trace metal required for a variety of enzymatic and cellular processes within the human body (Schroeder et al., 1966; Hurley, 1981; Grieger, 1999; Keen et al., 1999). Under normal dietary consumption, systemic homeostasis of $\mathrm{Mn}$ is maintained by both its rate of transport across enterocytes lining the intestinal wall and by its efficient removal within the liver (Papavasiliouet al., 1966). At the cellular level, Mn balance is proficiently managed by processes controlling cellular uptake, retention, and excretion. These processes are in delicate balance to maintain essential levels of $\mathrm{Mn}$ that fulfill nutritional requirements of the different organelles within the body. This

Correspondence to: Dr. Jerome A. Roth, Department of Pharmacology and Toxicology, 102 Farber Hall, University at Buffalo, Buffalo, NY 14214 USA, Tel.: (1-716) 829-3236, Fax: (1-716) 829-2801, E-mail: jaroth@ buffalo.edu 
normally efficient system of checks and balances that regulate $\mathrm{Mn}$ levels in vivo, however, appear to fail under conditions of exposure to chronic high doses of the metal, and thus, alterations in the elaborate homeostatic mechanisms are no longer adaptable to maintaining the status quo required.

Mn intoxication, a syndrome known as manganism, is most often associated with prolonged occupational exposure to abnormally high atmospheric concentrations of the metal. Neurological symptoms consist of reduced response speed, irritability, intellectual deficits, mood changes, and compulsive behaviors in the initial stages of the disorder to more prominent and irreversible extrapyramidal dysfunction resembling Parkinson's disease upon protracted exposure (Mena et al., 1969; Huang et al., 1993; Olanow et al., 1996; Mergler and Baldwin, 1997; Pal et al., 1999). Classic symptoms include masklike face, limb rigidity, mild tremors, gait disturbance, cock-like walk, slurred speech, excessive salivation and sweating and a disturbance of balance. Although $\mathrm{Mn}$ intoxication and Parkinson's disease are both associated with neurological changes in the basal ganglia, the latter disorder correlates with loss of dopaminergic neurons within the nigro-striatal pathway, whereas manganism is associated with the preferential degeneration of GABAminergic neurons within the globus pallidus, at least in the acute exposure paradigm and in the initial stages of the disorder (Olanow et al., 1996; Pal et al., 1999).

The strongest evidence indicating the sparing of neurons within the nigro-striatal pathway in manganism comes from studies demonstrating that fluorodopa scans are normal in individuals with high brain $\mathrm{Mn}$ levels (Olanow et al., 1996; Kim et al., 1998). Fluorodopa is a dopamine derivative that is taken up selectively within the presynaptic dopaminergic nerve endings in the striatum. The intensity of fluorodopa scans is depressed significantly in individuals with Parkinson's disease, indicative of the loss of dopaminergic neurons in the nigro-striatal pathway, whereas these scans are normal, for the most part, in individuals with high $\mathrm{Mn}$ content in blood and brain. Abnormal fluorodopa scans, however, have been reported recently in a patient with manganism, suggesting that overexposure to Mn may manifest in a more diffuse injury within the basal ganglia than generally acknowledged (Racette et al., 2005). These findings are consistent with studies demonstrating loss of neurons in the substantia nigra in rats treated with Mn for 18 months (Gupta et al., 1980) and with recent studies demonstrating $\mathrm{Mn}$-induced injury to the substantia nigra subsequent to degeneration of neurons within the globus pallidus of rats (Wright et al., 2004). Thus, the central nervous system (CNS) injury caused by $\mathrm{Mn}$ actually manifests in a diverse set of symptoms reflecting upon the fact that the basal ganglia is one of the most complex areas of the brain and associated with many positive and negative feedback loops in an attempt to preserve normal function. A disturbance in any one of these components, whether it occurs in the globus pallidus as in manganism or the nigrostriatal neurons as in Parkinson's disease, may manifest with insidious neurological deficits that are remarkably similar. In fact, there is not always a clear distinction in the expressed symptoms between the two disorders since the observed neurotoxic responses to $\mathrm{Mn}$ tend to vary greatly between individuals. Differences in response to Mn overexposure, most likely, are due to underlying genetic variability, which ultimately manifests in variation in both susceptibility and in the characteristics of the neurological lesions and symptoms expressed. The similarities in symptoms between the two disorders are not totally unexpected, since exposure to high levels of $\mathrm{Mn}$ is associated with elevated levels in both the globus pallidus and the substantia nigra, as seen in T1-weighted magnetic resonance imaging (MRI) scans (Hauser et al., 1994; Burkhard et al., 2003). Moreover, there also is increasing evidence that chronic exposure to elevated levels of $\mathrm{Mn}$ correlates with increased vulnerability to develop Parkinsonism, again implicating a possible common genetic component regulating these disorders (Pal et al., 1999; 
Gorell et al., 1999; Hudnell, 1999; Kim et al., 2002; Racette et al., 2001; Racette, 2005). This is consistent with the observation that chronic asymptomatic exposure to miners manifests in a detectable late-life abnormalities of movement (Hochberg et al., 1996). Similarly, markedly decreased D2 receptor density using $\mathrm{F}^{18}$-methylspiperone positron emission tomography (PET) scans have been reported during the very late stages of chronic manganese toxicity, suggesting that manganese intoxication may trigger a neurodegenerative disease process (Kessler, et al., 2003).

Actually Mn overexposure can manifest in a broad spectrum of symptoms not necessarily confined to or associated with the degeneration of the basal ganglia. For example, tremor and seizures were shown to develop in a 2-year-old girl receiving total parenteral nutrition (Komaki et al., 1999). In her case, blood Mn levels were elevated, and T1-weighted MRI images revealed areas of hyperintensity in the basal ganglia, brainstem, and cerebellum. Other studies suggested that Mn also may play a role in the pathogenesis of encephalopathy in patients with liver failure (Kreiger et al., 1995).

\section{ROUTES OF EXPOSURE TO MANGANESE}

As noted above, Mn intoxication generally is considered to be an occupational disorder confined to individuals mining the metal or those individuals working at or near industrial settings in which $\mathrm{Mn}$ is used in production or processing of other materials. Thus, welders and those working in or living near ferroalloy processing plants are at particular risk for developing manganism. The common feature in each of these exposure settings is elevated atmospheric levels of the metal that initially enter the body via the inspired ambient air. The Occupational Safety and Health Administration (OSHA) has set the permissible occupational airborne exposure limit (PEL) to $5 \mathrm{mg} / \mathrm{mm}^{3}$ based on an eighthour total weighted average exposure, whereas the current threshold limit value
(TLV) in the U.S. is set at $0.2 \mathrm{mg} / \mathrm{mm}^{3}$. There is strong sentiment, however, in much of the scientific community that these concentrations are actually set too high, since there is the potential risk that these concentrations are sufficient to provoke neurological damage in particularly susceptible individuals (Roels et al., 1987).

This raises an important question as to how $\mathrm{Mn}$ in inspired air actually enters the body and ends up in the brain. There are three potentially important routes by which Mn can gain access to the body: 1) direct uptake into the CNS via transport into the olfactory or trigeminal presynaptic nerve endings located in the nasal mucosa and the subsequent retrograde axonal delivery directly into the CNS; 2) transport across the pulmonary epithelial lining and its subsequent deposition into lymph or blood; and/or 3) mucocilliary elevator clearance from the lung and the subsequent ingestion of the metal in the gastrointestinal tract. The relative contribution of each of these to increasing the body burden of $\mathrm{Mn}$ is difficult to determine, although chances are that all three components factor into the final accumulated toxic levels observed.

Since the lung is the first organ exposed to $\mathrm{Mn}$, the events that take place within the respiratory tract will determine, without question, its biological availability. Deposition within the pulmonary airway of the inspired particulates containing $\mathrm{Mn}$ is dependent on the size, mass, and density of the particle. In general, ultrafine particles that are breathed in are rapidly exhaled without being deposited in the lung, whereas particles ranging from 0.02 to $1 \mu$ are preferentially deposited in the lower airway (Pityn et al, 1989; Yu et al, 2000). Larger particles, $(>5 \mu)$ in general, fail to penetrate the smaller branches of the respiratory tract and are mainly deposited in the upper airway. In addition to the site of deposition, several other factors ultimately govern biological availability of inspired $\mathrm{Mn}$ and include the composition of $\mathrm{Mn}$ within the particulate matter, the time of exposure within the lung, and how efficiently the metal is solubilized by macrophage within the lung. 
The first potential site for entry of inspired $\mathrm{Mn}$ into the body is a relatively unique process that allows for the direct transport of $\mathrm{Mn}$ into the brain, bypassing the blood-brain barrier. Numerous studies confirm that $\mathrm{Mn}$ is readily taken up within the nasal cavity in presynaptic nerve endings of axonal projections leading from the olfactory (Tjalve and Henriksson, 1999; Vitarella et al., 2000; Fechter et al., 2002; Dobson et al., 2003; Normandin et al., 2004; Dorman et al., 2002) and trigeminal nerves (Lewis et al., 2005). Mn that is taken up into these axons undergoes retrograde transport up the axons to the perikarya of the respective neurons within the CNS, where it is subsequently released into the interstitial space. The amount of $\mathrm{Mn}$ that is transported into brain via this route is dependent on its composition in the inhaled air with the more soluble forms being more efficiently taken up via this process. There also is evidence that extremely small ultrafine particles can be taken up by the nerve endings and subsequently delivered to the CNS via a similar retrograde transport process (Oberdorster et al., 2004). The majority of the studies examining this process have utilized the rat as a model, and therefore, the significance of this delivery system in humans should be viewed with some caution since the rat may not be a suitable paradigm for comparison in humans. The caveat lies in the fact that the nasal surface of the rat is almost 20 times greater than that for the human, and thus, the overall contribution of neuronal uptake process in primates may likely be attenuated.

The second process responsible for transport of $\mathrm{Mn}$, and that which probably represents the major factor contributing to its uptake, is transport across the pulmonary epithelial lining. Mn that is taken into the lung from inspired air is probably a complex mixture of soluble and insoluble Mn oxides along with aggregates of other metals. The particulate matter deposited in the lung is normally cleared by a process involving engulfment and the subsequent solubilization by pulmonary macrophage (Antilla, 1986; Lehnert, 1992; Antonini et al., 2004). Pulmonary macrophages represent approximately 3-5\% of all cells in the alveolar region (Lehnert, 1992), and the fundamental process of metal solubilization is facilitated by the acidic environment within the macrophage (Kreyling, 1992; Heilmann et al., 1992; Lundborg et al., 1992, 1995). Once solubilized, one of two things can happen: either Mn or some other potentially cytotoxic component within the particulate can provoke degeneration of the pulmonary macrophage (Antonini et al., 1999; Wesselius et al., 1999) or a specific transport processes can expel the solubilized metal back into the pulmonary fluid. Particulates that are liberated intact can again be rephagocitized, and the process of resolubilization will be resumed. The solubilized metal that is released is presumably transported across the epithelial lining of the lung by a transferrinindependent or transferrin-dependent process that is subject to the valence state of solubilized $\mathrm{Mn}$. If $\mathrm{Mn}^{+3}$ is released, it will bind avidly to transferrin present within the pulmonary fluid, whereas $\mathrm{Mn}^{+2}$ will bind to other proteins such as albumin (Wang et al., 2002; Yang et al., 2002). The transport proteins, divalent metal transporter 1 (DMT1) and ferroportin, are both present within the alveolar epithelial cells lining the pulmonary/blood partition, presumably to aid in the transport of metals across the alveolar cells for deposition in the lymphatic system or directly into blood (Wang et al., 2002; Yang et al., 2002). In addition to this carrier-mediated system, there is also the possibility that Mn, which is complexed to transferrin in the pulmonary fluid, can be directly transported across the epithelium by the process of transcytosis, as recently reported for the GCSF-transferrin complex (Widera et al., 2003a,b). In this case, the Mn-TfR complex, located within the endosomal or pinocytotic vesicles that are formed, transverses directly from the apical-tobasolateral surface of the alveolar cell lining the pulmonary/blood interface. It also is feasible that over an extended period of time the accumulated $\mathrm{Mn}$ and other noxious components of particulates can lead to disruption of the epithelial cells, allowing the direct access of the metals into the 
circulatory system (Pascal and Tessier, 2004). It is difficult to quantitate the extent to which pulmonary uptake contributes to the overall increase of $\mathrm{Mn}$ in blood and brain seen in miners and welders, but it is likely to represent the major route for entry of metals into the body. It is important to realize the fact that much of the $\mathrm{Mn}$ that accumulates in the lung persists for extended periods of time, having a biphasic half-life in the lung of 2 and 125 days (Kalliomaki et al., 1983), thus allowing the biological systems that are in place to eventually solubilize the metal within the particulates, thus favoring its entry into the fluids of the body.

The remaining Mn within the pulmonary fluid, whether it represents particulate or solubilized $\mathrm{Mn}$ that is bound to proteins or present in macrophage, will undergo mucocilliary escalator transport up the bronchioles, where it is eventually ingested and enters the digestive system. It is estimated, at least in the rat, that approximately $2.4 \%$ of the alveolar macrophage are transported to the upper respiratory tract daily (Fritsch and Masse, 1992). The fate of $\mathrm{Mn}$ ingested via the mucocilliary escalator likely will behave within the intestinal tract in a similar fashion as dietary Mn. The stomach, being approximately $\mathrm{pH} 2$, readily dissolves complexed metal allowing for its subsequent uptake within the intestinal tract. The emptying time for the stomach varies considerably from 1 to $5 \mathrm{hrs}$ and is largely dependent on content of the stomach. Thus, the extent to which $\mathrm{Mn}$ is solubilized within the stomach is a function of its concentration and composition as well as the presence of other ingested foods, which directly impacts on emptying time. Solubilized $\mathrm{Mn}$ that is released from the stomach into the duodenum is transported across the microvilli into blood via the transport protein, DMT1 and ferroportin (Canonne-Hergaux et al., 1999; Trinder et al., 2000; Knopfel et al., 2005). The percentage for $\mathrm{Mn}$ entering the intestines from mucocilliary escalator is not known nor is it known what percentage is actually absorbed into the body via this route. Assuming it behaves like dietary Mn, we anticipate uptake to only be around 5\% suggesting that a small percentage of $\mathrm{Mn}$ from inspired air actually will enter the blood stream via the gastrointestinal tract (Davidsson et al., 1989; Johnson et al., 1991).

Although the mechanism responsible for the delivery of $\mathrm{Mn}$ from inspired air into the body is still under investigation, the literature is unequivocal about the fact that the levels of Mn are elevated significantly in blood and brains of individuals exposed to high levels of $\mathrm{Mn}$ in the environmental workplace. Regardless of the route of entry, its prevalence is brought about by its protracted accumulation on a daily basis to high levels of the metal in particulate matter. The accumulated $\mathrm{Mn}$ in the lung more than likely reaches a steady state in which increased stores are met with an equal rate of elimination ultimately leading to enhance uptake and the creation of noxious levels within the body.

\section{BLOOD - BRAIN BARRIER}

Other than the direct uptake of Mn via the olfactory or trigeminal nerves, Mn must cross the blood-brain barrier to get into the brain. Unfortunately, the mechanism for transport of $\mathrm{Mn}$ across the endothelial cells lining the cerebral vasculature has not been identified satisfactorily, as there is considerable conflicting data in the literature as to the actual biochemical processes involved. Substantial evidence has been presented in recent years indicating that $\mathrm{Mn}$ is transported into these cells via DMT1, in a transferrin-dependent or possibly a transferrin-independent process (Burdo et al., 2001, 2004; Zheng et al., 2003; Wu et al., 2004; Roth and Garrick, 2003). Arguments in favor of DMT1 being the major transport protein responsible for $\mathrm{Mn}$ uptake is based on several observations including the fact that DMT1 is present in the vasculature wall along with the transferrin receptor (Burdo et al., 2001) and ferroportin 1 (Wu et al., 2004), the protein assumed to be involved in export of $\mathrm{Mn}$ out of the vascular endothelial cell. DMT1 expression has been 
reported to be regulated by iron status with low iron increasing DMT1 expression (Oates et al., 2000; Moos et al., 2002; Erikson et al. 2004). Several studies have reported that $\mathrm{Mn}$ accumulation in the CNS is, in fact, elevated during iron deficiency, supporting the hypothesis that DMT1 is involved in this uptake process (Erikson et al. 2002, 2004). In addition, the Belgrade rat, which has a mutation in DMT1 that essentially makes it inactive, has decreased brain levels of Mn and other divalent metals known to be transported by this protein (Burdo et al., 2001). The major arguments against DMT1 playing a role in $\mathrm{Mn}$ transport into the CNS come from the studies of Moos and Morgan (2004), Takeda et al. (2000) and Yokel and Crossgrove (2004). Their findings reveal that the $\mathrm{Mn} /$ transferrin-complex is not the most favorable species of the metal capable of crossing the blood-brain barrier and that DMT1 is not present in capillary endothelial cells. Yokel and Crossgrove (2004) have further demonstrated that the neutral $\mathrm{pH}$ optimum observed for $\mathrm{Mn}$ transport into the CNS is inconsistent with the expected acidic $\mathrm{pH}$ optimum found for DMT1-mediated uptake. These investigators propose that store-operated $\mathrm{Ca}$ channels, as well as other mechanisms, are responsible for the transport of $\mathrm{Mn}$ across the blood-brain barrier (Crossgrove and Yokel, 2005). The evidence against a transferrin-DMT1-dependent process, however, is not sufficient to exclude the possibility that DMT1 plays a role in Mn transport across the blood brain barrier. The studies of both Takeda et al., (2000) and Yokel and Crossgrove (2004) may be explained by the fact that transferrindependent transport into the endothelial cell may not be the rate-limiting step for $\mathrm{Mn}$ transfer into the CNS. Instead, we also have to consider the possibility that transport of Mn out of the cell may be rate limiting, and this may occur at optimal $\mathrm{pH}$ near neutrality. This suggestion recently has been introduced for $\mathrm{Fe}$ transport across enterocytes cells (Beutler, 2004). It is also feasible that $\mathrm{Mn}$ can cross the blood-brain barrier complexed to transferrin by a process involving transcytosis (Fenart and
Cecchelli, 2003; Moroo et al., 2003). Obviously, further studies are necessary to adequately characterize the specific mechanisms responsible for the transport of Mn across the cerebral vasculature.

MANGANESE HOMEOSTASIS: NUTRITIONAL REQUIREMENTS, BLOOD SPECIATION AND LIVER

As noted above, $\mathrm{Mn}$ is an essential trace mineral required for normal growth and development. Deficiency of $\mathrm{Mn}$ is extremely rare in the adult, although neurological and behavioral deficits as well as other abnormalities have been observed during development (Hurley, 1981; World Health Organization, Environmental Health Criteria, 1981; Keen et al. 1999; Grieger, 1999). The total body burden of Mn for the standard $70 \mathrm{~kg}$ man is estimated to be approximately 10 to $20 \mathrm{mg}$ of which 25 to $40 \%$ is present in bone. Concentrations in most adult tissues range between 3 and 20 $\mu \mathrm{M}$.

Other than occupational exposures, the major source of $\mathrm{Mn}$ is from our diet. Foods that are particularly rich in $\mathrm{Mn}$ include cereal, vegetables, fruits, nuts, spices and beverages such as wine, tea and coffee (Wenlock et al., 1979; Gillies and Birkbeck, 1983). The ubiquitous presence of $\mathrm{Mn}$ in a variety of foods accounts for the fact that Mn deficiency in the adult is practically nonexistent. The average daily intake is estimated to be between 3 and $9 \mathrm{mg} /$ day which is greater than the recommended daily allowance of $2.3 \mathrm{mg} /$ day set by the FDA in the U.S. Overdoses from dietary intake of $\mathrm{Mn}$ are unlikely, as approximately $5 \%$ of the Mn ingested actually ends up in the body via the intestines (Davidsson et al., 1989; Johnson et al., 1991).

The ionic species of $\mathrm{Mn}$ that enters the blood stream from the intestines is not known but will have a major impact on the fate of $\mathrm{Mn}$ retained in the body. As noted above, the liver plays a vital role in regulating $\mathrm{Mn}$ levels in vivo principally because it is the major route for its elimination. Hepatic elimination of $\mathrm{Mn}$, however, is greatly dependent on the $\mathrm{Mn}$ protein complex present in serum. $\mathrm{Mn}^{+3}$, 
the predominant form in blood, is bound tightly to transferrin (Gibbons et al., 1976) and, under normal conditions, is not in direct competition with bound $\mathrm{Fe}^{+3}$, since only $30 \%$ of the available binding sites on transferrin are typically bound by iron. This raises an interesting question as to the fate of $\mathrm{Mn}$ in blood in conditions such as sickle cell anemia or hemochromatosis where transferrin may be totally saturated with iron. $\mathrm{Mn}^{+3}$ has a high affinity for transferrin (Gibbons et al., 1976), but its ability to compete with iron under these conditions has not been examined. Because $\mathrm{Mn}^{+3}$ forms a stable complex with transferrin, hepatic removal is relatively slow and comparable to that for $\mathrm{Tf}-\mathrm{Fe}^{+3}$ complex. $\mathrm{Mn}^{+2}$ in blood is preferentially bound to a2macroglobulin, although because of the significantly greater abundance of albumin in serum, a large percentage also is presumed to be bound to this latter protein, as well. The ligand interaction between $\mathrm{Mn}^{+2}$ and serum proteins is rather weak accounting for the rapid hepatic elimination from blood. Unlike $\mathrm{Fe}^{+2}$, oxidation of $\mathrm{Mn}^{+2}$ to $\mathrm{Mn}^{+3}$ does not occur spontaneously in vivo and probably requires the coppercontaining enzyme, ceruloplasmin, or the equivalent to support this conversion. Importantly, $\mathrm{Mn}^{+2}$ is essentially the only oxidation state of $\mathrm{Mn}$ that is seen intracellularly.

Thus, by regulating the body burden of $\mathrm{Mn}$, the liver can directly influence brain levels upon chronic exposure to abnormally high levels of the metal (Papavasiliou et al., 1966). Since welders and miners experience substantially elevated Mn blood and brain levels, the assumption must be made that, under these conditions, the liver is incapable of keeping up with the demands to maintain normal homeostatic concentrations. This may partially be explained by the fact that much of the Mn from inspired air that is transported across the pulmonary epithelium is absorbed into tissues prior to it ever being encountered by the liver.

Mn toxicity is not only restricted to clusters of occupational exposed workers but also is seen in individuals with cirrhosis of the liver and related hepatic dysfunction
(Krieger et al., 1995; Hauser et al., 1994, 1996; Spahr et al., 1996; Burkhard et al., 2003). These individuals express both elevated blood and brain levels of $\mathrm{Mn}$ and display many of the behavioral and neurological symptoms associated with this disorder. Based on T1-weighted MRI scans, Mn levels were elevated in both the globus pallidus and substantial nigra (Hauser et al., 1994). The observation of elevated $\mathrm{Mn}$ in patients with liver failure is not unexpected, given the fact that hepatic elimination of $\mathrm{Mn}$ is the normal route for its removal from the body and anything that disrupts normal hepatic function has the potential to provoke elevated systemic levels of the metal. A similar situation occurs for individuals receiving parenteral nutrition, since they also display classical symptoms of Mn overexposure (Reimund et al., 2000; Fok et al., 2001; Suzuki et al., 2003; Iinuma et al., 2003). Thus, when evaluating the contribution of the various factors that potentially influence Mn toxicity, we must not only include the different routes of delivery but also the ability of the liver to remove the various species of $\mathrm{Mn}$ that exist in blood.

\section{TRANSPORT OF MN}

Within the past decade, various transport mechanisms that are responsible for cellular uptake of $\mathrm{Mn}^{+2}$ and other divalent transition metals have been identified. These studies reveal that $\mathrm{Mn}$ is transported into cells via a mechanism similar to that for iron, as evidenced by the fact that both Mn and iron, as well as several other divalent transition metals, compete for uptake into a number of different cell systems (Gunshin et al., 1997; Roth et al., 2002, 2003). As illustrated in figure 1, there are two distinct but related mechanisms responsible for the transport of $\mathrm{Mn}$ and ferrous ion: a transferrin-dependent and a transferrin independent pathway. As illustrated, the transferrin dependent pathway proposes that the transferrin- $\mathrm{Mn}^{+3}$ complex initially binds to the transferrin receptor (TfR) on the cell surface similar to that which occurs for iron. After attachment of $\mathrm{Tf}$ to the $\mathrm{TfR}$, endosomal vesicles that are 
formed at the cell surface are internalized and subsequently acidified by a hydrogen ion ATPase pump causing release of the metal from the Tf/TfR complex. $\mathrm{Mn}^{+3}$ released into the vesicles is presumably reduced to $\mathrm{Mn}^{+2}$ although a specific reductase responsible for this reaction has not been identified. $\mathrm{Mn}^{+2}$ is subsequently transported across the endosomal membrane via the transport protein, divalent metal transporter 1 (DMT1; also named Nramp2, DCT1 or SLC11A2) (Gunshin et al., 1997; Fleming et al., 1997; Fleming et al., 1998). Since $\mathrm{Mn}^{+2}$ forms a relatively weak complex with either a2-macroglobulin or serum albumin, there is also the possibility that transport of $\mathrm{Mn}^{+2}$ released from this complex can be taken up directly at the cell surface by DMT1, independent of transferrin. Which of the two uptake mechanisms functionally predominates is likely to be cell specific and dependent on the presence of TfR on the cell surface. In addition to cellular uptake by DMT1, there is also evidence in the literature, as illustrated in figure 1, for transport of $\mathrm{Mn}$ via the voltage regulated and store-operated $\mathrm{Ca}^{+2}$ channels, as well as the ionotropic glutamate receptor $\mathrm{Ca}^{+2}$ channels (Lucaciu et al., 1997; Kannurpatti et al., 2000; Riccio et al., 2002). In each of these processes, Mn transport requires an external signal to initiate its entry into the cell such as membrane depolarization, agonist mediated depletion of $\mathrm{Ca}^{+2}$ stores, or glutamate attachment to its receptor, respectively. The extent to which these processes contribute to the overall cellular uptake of $\mathrm{Mn}$ is not known, however as noted above, recent evidence suggests that the store-operated $\mathrm{Ca}^{+2}$ channels may play an important role in the transport of $\mathrm{Mn}$ across the blood-brain barrier (Crossgrove and Yokel, 2005).

\section{CYTOTOXIC MECHANISMS OF MANGANESE}

Considerable progress has been made within the past decade regarding the mechanism by which Mn induces cell death. Both apoptosis and necrosis have been implicated in provoking $\mathrm{Mn}$-induced cell toxicity with differences in the mechanisms reflecting variation in the signaling processes and disposition of Mn in different cells. There is strong evidence that apoptosis contributes to $\mathrm{Mn}$ toxicity, since many of the classical markers and signaling pathways associated with programmed cell death are activated in cells treated with Mn. These include: increased TUNEL staining; internucleosomal DNA cleavage; activation of the JNK and p38 (stress-activated protein kinase); activation of caspase activity; cytochrome c release; and caspase-dependent cleavage of PARP (Desole et al., 1996, 1997; Hirata et al., 1998; Schrantz et al., 1999; Roth et al., 2000; Chun et al., 2001; Latchoumycandane et al., 2005). In addition, Bcl-2 overexpression is capable of preventing $\mathrm{Mn}$ stimulated toxicity (Schrantz et al., 1999; Kitazawa et al., 2005).

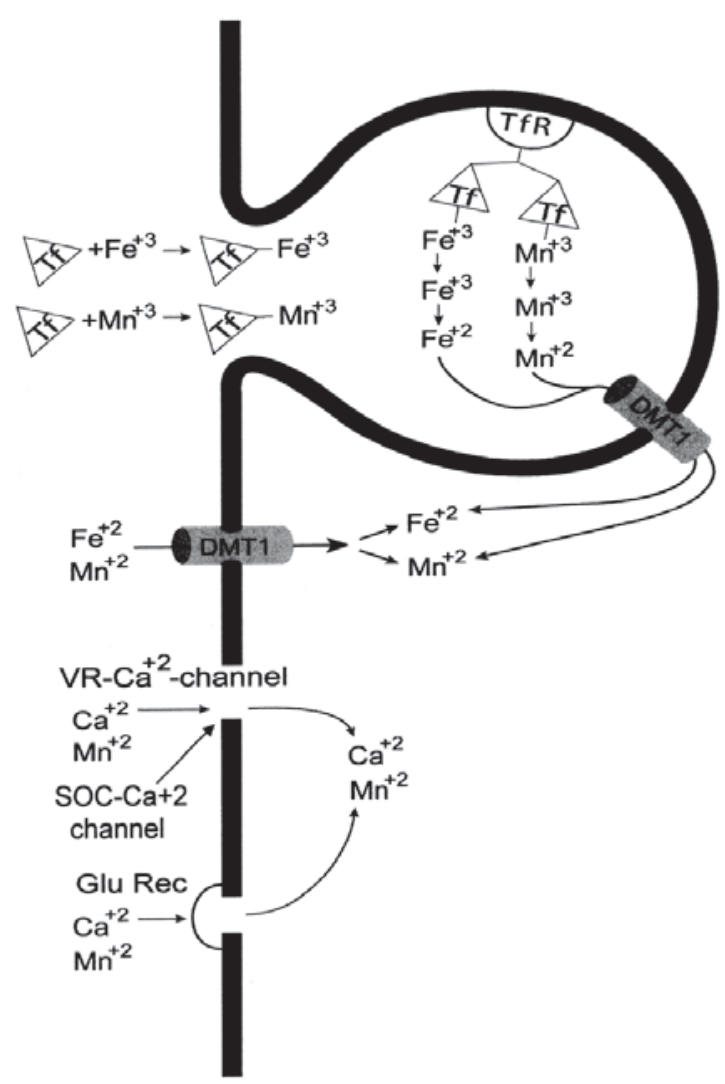

Figure 1. Transport mechanisms responsible for the uptake of manganese. Tf - transferrin; TfR transferrin receptor; DMT1 - divalent metal transporter 1; VR - voltage gated $\mathrm{Ca}^{+2}$ channel; SOC - store operated $\mathrm{Ca}^{+2}$ channel; Glu Rec glutamic acid ionotropic receptor. 
In contrast, other studies have suggested that $\mathrm{Mn}$ is, in fact, a potent antioxidant capable of suppressing oxidative-initiated events within the cell (Sziraki et al., 1995, 1998, 1999; Talavera et al., 1999; Roth et al., 2000). Studies in our laboratory have shown that Mn toxicity is probably not solely due to apoptosis, since inhibitors of several classic apoptotic markers fail to prevent cytotoxicity (Roth et al., 2000). For example, selective inhibitors of both the caspase family of proteases and the stressactivated protein kinase, p38, do not prevent Mn toxicity in PC12 cells, even though these apoptotic markers are stimulated upon treatment with Mn. Thus, other cytotoxic events must be responsible for the observed cell death initiated by Mn. Several studies have reported that $\mathrm{Mn}$ is capable of inducing mitochondrial membrane transients leading to disruption of mitochondrial function (Gavin et al., 1992, 1999). These investigators have proposed that $\mathrm{Mn}$ promotes calcium accumulation within the mitochondria by inhibiting both the sodium-dependent and sodium-independent exporter, resulting in the activation of the permeability transition pore (PTP) and loss of mitochondrial function. In addition, Mn also can interfere with oxidative phosphorylation by inhibiting both mitochondrial F1-ATPase (Gavin et al., 1992, 1999) and complex I (Galvani et al., 1995), causing a depletion of ATP (Brouillet et al., 1993; Roth et al., 2000; Chen and Liao, 2002; Zhang et al., 2005). Thus, either apoptosis or necrosis may lead to the ultimate demise of the cell integrity with the predominant cytotoxic pathway most likely being cell specific.

Because of the similarities between the neurological symptoms associated with manganism and Parkinson's disease, most research efforts in the past have focused on model cell systems in which dopamine is the principal neurotransmitter. Although considerable information has been profited from these studies, it is reasonable to assume that signaling events controlling $\mathrm{Mn}$ cytotoxicity may be considerably different than those provoking cell death within the neurons of the globus pallidus, since these neurons do not contain dopamine (Olanow et al. 1996; Mergler and Baldwin, 1997). Pallidal neurons are GABAminergic and receive glutaminergic input from the subthalamic nuclei. Because of this, there have been a number of studies that have attempted to examine the actions of the excitatory neurotransmitter, glutamate, on Mn-induced toxicity (Plenz et al., 1998; Rouse et al., 2000). Results of these studies implicate glutamate as a potential contributing factor to the toxicity of $\mathrm{Mn}$ within pallidal neurons and suggest that toxicity is not caused by any one factor but, instead, result from an amalgamation of several events occurring simultaneously, the center of which includes accumulation of glutamate in this area of the brain. These factors include: 1) excess accumulation of Mn in the globus pallidus; 2) Mn inhibition of glutamate transport leading to increase synaptic levels of glutamate (Hazell and Norenberg, 1997; Erikson and Aschner, 2002); and 3) increased uptake of $\mathrm{Mn}$ in pallidal neurons by activated glutamate channels (Kannurpatti et al., 2000). This hypothesis is supported by the studies of Brouillet and coworkers (1993) demonstrating that the noncompetitive NMDA receptor antagonist, $\mathrm{MK}-801$, is capable of blocking lesions produced by intrastriatal injections of Mn.

\section{CONCLUSIONS}

The studies above attempt to summarize and clarify our basic knowledge as to the various factors that potentially influence the risks imposed from chronic exposure to high atmospheric levels of Mn. These studies endeavored to define the interrelationship of the different systems in the body that regulate $\mathrm{Mn}$ homeostasis by characterizing specific biological components involved in its systemic and cellular uptake, transport in blood and delivery to organelles, retention in the brain and other target organs, and its elimination from the body. Results from these studies have begun to define environmental and dietary conditions, such as iron deficiency, that alter the biological parameters that maintain normal iron balance and to explain 
how these changes may result in adverse conditions that actually support and accelerate $\mathrm{Mn}$ toxicity. It is reasonable to hypothesize that genetic and environmental factors regulating susceptibility to develop $\mathrm{Mn}$ toxicity also may influence vulnerability to acquire Parkinson's disease, since physiological processes controlling the two disorders are multifaceted, contingent on the interdependence of many overlapping biochemical and molecular systems within the body. To fully understand these relationships, future studies will need to focus on genetic differences in the population that regulate vulnerability to develop Mn toxicity and that control the expressed symptoms in this disorder.

\section{ACKNOWLEDGEMENTS}

This work was supported by grant from National Institute of Environmental Health Sciences (\#R01 ES11127). As a result of my research on manganese toxicity, I have been retained as an expert witness by parties in litigation involving manganese.

\section{REFERENCES}

ANTILLA, S (1986) Dissolution of stainless steel welding fumes in the rat lung; an X-ray microanalytical study. Br J Ind Med 43: 592-596

ANTONINI JM, LAWRYK NJ, MURTHY GG, BRAIN JD (1999) Effect of welding fume solubility on lung macrophage viability and function in vitro. $\mathrm{J}$ Toxicol Environ Health A 58: 343-363

ANTONINI JM, TAYLOR MD, ZIMMER AT, ROBERTS JR (2004) Pulmonary responses to welding fumes: Role of metal constituents. J Toxicol Environ Health A 67: 233-249

BEUTLER E (2004) "Pumping" iron: The proteins. Science 306: $2051-2053$

BROUILLET EP, SHINOBU L, MCGARVEY U, HOCHBERG F, BEAL MF (1993) Manganese injection into the rat striatum produces excitotoxic lesions by impairing energy metabolism. Exp Neurol 120: 89-94

BURDO JR, MENZIES SL, SIMPSON IA, GARRICK LM, GARRICK MD, DOLAN KG, HAILE DJ, BEARD JL, CONNOR JR (2001) Distribution of divalent metal transporter 1 and metal transport protein 1 in the normal and Belgrade rat. J Neurosci Res 66: 11981207

BURDO JR, SIMPSON IA, MENZIES S, BEARD J, CONNOR JR (2004) Regulation of the profile of ironmanagement proteins in brain microvasculature. J Cereb Blood Flow Metab 24: 67-74
BURKHARD PR, DELAVELLE J, DU PASQUIER R, SPAHR L (2003) Chronic parkinsonism associated with cirrhosis: A distinct subset of acquired hepatocerebral degeneration. Arch Neurol 60: 521-528

CANONNE-HERGAUX F, GRUENHEID S, PONKA P, GROS P (1999) Cellular and subcellular localization of the Nramp2 iron transporter in the intestinal brush border and regulation by dietary iron. Blood 93: 44064417

CHEN CJ, LIAO SL (2002) Oxidative stress involves in astrocytic alterations induced by manganese. Exp Neurol 175: 216-225

CHUN HS, LEE H, SON JH (2001) Manganese induces endoplasmic reticulum (ER) stress and activates multiple caspases in nigral dopaminergic neuronal cells, SN4741. Neurosci Lett 316: 5-8

CROSSGROVE JS, YOKEL RA (2005) Manganese distribution across the blood-brain barrier: IV. Evidence for brain influx through store-operated calcium channels. Neurotoxicol 26: 297-307

DAVIDSSON L, CEDERBLAD A, LONNERDAL B SANDSTROM B (1989) Manganese retention in man: A method for estimating manganese absorption in man. Am J Clin Nutr 49: 170-179

DESOLE MS, SCIOLA L, DELOGU MR, MIGHELI R, SIRCANA S, MIGHELI R (1996) Manganese and 1methyl-4-(2'-ethylphenyl)-1,2,3,6-tetrahydropyridine induce apoptosis in PC12 cells. Neurosci Let 209: 193196

DESOLE MS, SCIOLA L, DELOGU MR, SIRCANA, S, MIGHELI R, MIELE E (1997) Role of oxidative stress in the manganese and 1-methyl-4-(2'-ethylphenyl)1,2,3,6-tetrahydropyridine-induced apoptosis in PC12 cells. Neurochem Int 31: 169-176

DOBSON AW, WEBER S, DORMAN DC, LASH LK, ERIKSON KM, ASCHNER M (2003) Oxidative stress is induced in the rat brain following repeated inhalation exposure to manganese sulfate. Biol Trace Elem Res 93: $113-126$

DORMAN DC, BRENNEMAN KA, MCELVEEN AM, LYNCH SE, ROBERTS KC, WONG BA (2002) Olfactory transport: A direct route of delivery of inhaled manganese phosphate to the rat brain. J Toxicol Environ Health A 65: 1493-1511

ERIKSON K, ASCHNER M (2002) Manganese causes differential regulation of glutamate transporter (GLAST) taurine transporter and metallothionein in cultured rat astrocytes. Neurotoxicol 23: 595-602

ERIKSON KM, SHIHABI ZK, ASCHNER JL, ASCHNER M (2002) Manganese accumulates in iron-deficient rat brain regions in a heterogeneous fashion and is associated with neurochemical alterations, Biol Trace Elem Res 87: 143-156

ERIKSON KM, SYVERSEN T, STEINNES E, ASCHNER M (2004) Globus pallidus: A target brain region for divalent metal accumulation associated with dietary iron deficiency. J Nutr Biochem 15: 335-341

EVERITT JI (2004) Nasal toxicity of manganese sulfate and manganese phosphate in young male rats following subchronic (13-week) inhalation exposure. Inhal Toxicol 2004 16: 481-488

FECHTER LD, JOHNSON DL, LYNCH RA (2002) The relationship of particle size to olfactory nerve uptake of a non-soluble form of manganese into brain. Neurotoxicol 23: 177-183

FENART L, CECCHELLI R (2003) Protein transport in cerebral endothelium. In vitro transcytosis of transferrin. Methods Mol Med 89: 277-290

FLEMING MD, ROMANO MA, SU MA, GARRICK LM, GARRICK MD, ANDREWS NC 91998) Nramp2 is 
mutated in the anemic Belgrade $(b)$ rat: Evidence of a role for Nramp2 in endosomal iron transport. Proc Natl Acad Sci USA 95: 1148-1153

FLEMING MD, TRENOR CC, SU MA, FOERNZLER D, BEIER DR, DIETRICH WF, ANDREWS NC (1997) Microcytic anaemia mice have a mutation in Nramp2, a candidate iron transporter gene. Nature Genet 16: 383386

FOK TF, CHUI KK, CHEUNG R, NG PC, CHEUNG KL, HJELM M (2001) Manganese intake and cholestatic jaundice in neonates receiving parenteral nutrition: A randomized controlled study. Acta Paediatr 90: 10091015

FRITSCH P, MASSE R (1992) Overview of pulmonary alveolar macrophage renewal in normal rats and during different pathological processes. Environ Health Perspect 97: 59-67

GALVANI P, FUMAGALLI P, SANTAGOSTINO A (1995) Vulnerability of mitochondrial complex $I$ in PC12 cells exposed to manganese. Eur J Pharmacol Environ Toxicol 293: 377-383

GAVIN CE, GUNTER K, GUNTER TE (1992) $\mathrm{Mn}^{2+}$ sequestration by mitochondria and inhibition of oxidative phosphorylation. Toxicol Appl Pharmacol 115: $1-5$

GAVIN CE, GUNTER KK, GUNTER TE (1999) Manganese and calcium transport in mitochondria: Implications for manganese toxicity. Neurotoxicol 20: 445-454

GIBBONS RA, DIXON SN, HALLIS K, RUSSELL AM, SANSOM BF, SYMONDS HW (1976) Manganese metabolism in cows and goats. Biochim Biophys Acta 444: $1-10$

GILLIES ME, BIRKBECK JA (1983) Tea and coffee as sources of some minerals in the New Zealand diet. Am J Clin Nutr 38: 936-942

GORELL JM, JOHNSON CC, RYBICKI BA, PETERSON EL, KORTSHA GX, BROWN GG, RICHARDSON RJ (1999) Occupational exposure to manganese, copper, lead, iron, mercury and zinc and the risk of Parkinson's disease. Neurotoxicol 20: 239-248

GOSK S, VERMEHREN C, STORM G, MOOS T (2004) Targeting anti-transferrin receptor antibody (OX26) and OX26-conjugated liposomes to brain capillary endothelial cells using in situ perfusion. J Cereb Blood Flow Metab 24: 1193-1204

GRIEGER JL (1999) Nutrition versus toxicology of manganese in humans: Evaluation of potential markers. Neurotoxicol 20: 205-212

GUNSHIN H, MACKENZIE B, BERGER UV, GUNSHIN Y, ROMERO MF, BORON WF, NUSSBERGER S, GOLLAN JL, HEDIGER MA (1997) Cloning and characterization of a mammalian proton-coupled metalion transporter. Nature 388: 482-488

GUPTA SK, MURTHY RC, CHANDRA SV (1980) Neuromelanin in manganese-exposed primates. Toxicol Lett 6: 17-20

HAUSER RA, ZESIEWICZ TA, ROSEMURGY AS, MARTÍNEZ C, OLANOW CW (1994) Manganese intoxication and chronic liver failure. Annals Neurol 36: $871-875$

HAUSER RA, ZESIEWICZ TA, MARTÍNEZ C, ROSEMURGY AS, OLANOW CW (1996) Blood manganese correlates with brain magnetic resonance imaging changes in patients with liver disease. Can J Neurol Sci 23: 95-98

HAZELL AS, NORENBERG MD (1997) Manganese decreases glutamate uptake in cultured astrocytes. Neurochem Res 22: 1443-1447

HEILMANN P, BEISKER W, MIASKOWSKI U,
CAMNER P, KREYLING WG (1992) Intraphagolysosomal $\mathrm{pH}$ in canine and rat alveolar macrophages: Flow cytometric measurements. Environ Health Perspect 97: 115-120

HIRATA Y, ADACHI K, KIUCHI K (1998) Activation of JNK pathway and induction of apoptosis by manganese in PC12 cells. J Neurochem 71: 1607-1615

HOCHBERG $\mathrm{F}$, MILLER G, VALENZUELA R, MCNELIS S, CRUMP KS, COVINGTON T, VALDIVIA G, HOCHBERG B, TRUSTMAN JW (1996) Late motor deficits of Chilean manganese miners: A blinded control study. Neurol 47: 788-795

HUANG CC, LU CS, CHU NS, HOCHBERG F, LILIENFELD D, OLANOW W, CALNE DB. (1993) Progress after chronic manganese exposure. Neurol 43: 1479-1483

HUDNELL HK (1999) Effects from environmental Mn exposures: A review of the evidence from nonoccupational exposure studies. Neurotoxic 20: 379-397

HURLEY LS (1981) Teratogenic aspects of manganese, zinc, and copper nutrition. Physiol Rev 61: 249-295

IINUMA Y, KUBOTA M, UCHIYAMA M, YAGI M, KANADA S, YAMAZAKI S, MURATA H, OKAMOTO K, SUZUKI M, NITTA K (2003) Wholeblood manganese levels and brain manganese accumulation in children receiving long-term home parenteral nutrition. Pediatr Surg Int 19: 268-272

JOHNSON PE, LYKKEN GI, KORYNTA ED (1991) Absorption and biological half-life in humans of intrinsic and extrinsic ${ }^{54} \mathrm{Mn}$ tracers from foods of plant origin. J Nutr 121: 711-717

KALLIOMAKI PL, TUOMISAARI M, LAKOMAA EL, KALLIOMAKI K, KIVELA R (1983) Retention and clearance of stainless steel shieldgas welding fumes in rat lungs. Am Ind Hyg Assoc , 44: 649-654

KANNURPATTI SS, JOSHI PG, JOSHI NB (2000) Calcium sequestering ability of mitochondria modulates influx of calcium through glutamate receptor channel. Neurochem Res 25: 1527-1536

KEEN CL, ENSUNSA JL, WATSON MH, BALY D., DONAVAN SM, MONACO MH, CLEGG MS (1999) Nutritional aspects of manganese from experimental studies. Neurotoxicol 20: 213-224

KESSLER KR, WUNDERLICH G, HEFTER H, SEITZ RJ (2003) Secondary progressive chronic manganism associated with markedly decreased striatal D2 receptor density. Mov Disord 18: 217-218

KIM JW, KIM Y, CHEONG HK, ITO K (1998) Manganese induced parkinsonism: A case report. J Korean Med Sci 13: 437-439

KIM Y, KIM JM, KIM JW, YOO CI, LEE CR, LEE JH, KIM HK, YANG SO, CHUNG HK, LEE DS, JEON B. (2002) Dopamine transporter density is decreased in parkinsonian patients with a history of manganese exposure: What does it mean? Mov Disord 17: 568575

KITAZAWA M, ANANTHARAM V, YANG Y, HIRATA Y, KANTHASAMY A, KANTHASAMY AG (2005a) Activation of protein kinase $\mathrm{C}$ delta by proteolytic cleavage contributes to manganese-induced apoptosis in dopaminergic cells: protective role of $\mathrm{Bcl}-2$. Biochem Pharmacol 69: 133-146

KNOPFEL M, ZHAO L, GARRICK MD (2005) Transport of divalent transition-metal ions is lost in smallintestinal tissue of $b / b$ Belgrade rats. Biochemistry 44 : 3454-6534

KOMAKI H, MAISAWA S, SUGAI K, KOBAYASHI Y, HASHIMOTO T (1999) Tremor and seizures associated with chronic manganese intoxication. Brain Dev 21: 122-4 
KREYLING WG (1992) Intracellular particle dissolution in alveolar macrophages. Environ Health Perspect 97: 121-126

KRIEGER D, KRIEGER S, JANSEN O, GASS P, THEILMANN L， LICHTNECKER H (1995) Manganese and chronic hepatic encephalopathy. Lancet 346: $270-274$

LATCHOUMYCANDANE C, ANANTHARAM V, KITAZAWA M, YANG Y, KANTHASAMY A, KANTHASAMY AG (2005) Protein kinase Cdelta (PKC $\{$ delta $\})$ is a key downstream mediator of manganese-induced apoptosis in dopaminergic neuronal cells. J Pharmacol Exp Ther 313: 46-55

LEHNERT BE (1992) Pulmonary and thoracic macrophage subpopulations and clearance of particles from the lung. Environ Health Perspect 97: 17-46

LEWIS J, BENCH G, MYERS O, TINNER B, STAINES W, BARR E, DIVINE KK, BARRINGTON W, KARLSSON J (2005) Trigeminal uptake and clearance of inhaled manganese chloride in rats and mice. Neurotoxicol 26: 113-123

LUCACIU CM, DRAGU C, COPAESCU L, MORARIU VV (1997) Manganese transport through human erythrocyte membranes. An EPR study. Biochim Biophys Acta 1328: 90-98

LUNDBORG M, FALK R, JOHANSSON A, KREYLING W, CAMNER P (1992) Phagolysosomal pH and dissolution of cobalt oxide particles by alveolar macrophages. Environ Health Perspect 97: 153-157

LUNDBORG M, JOHARD U, JOHANSSON A, EKLUND A, FALK R, KREYLING W, CAMNER P (1995) Phagolysosomal morphology and dissolution of cobalt oxide particles by human and rabbit alveolar macrophages. Exp Lung Res 21: 51-66

MENA I, HORIUCHI K, BURKE K, COTZIAS GC (1969) Chronic manganese poisoning. Individual susceptibility and absorption of iron. Neurol 19: 1000-1006

MERGLER D, BALDWIN M (1997) Early manifestations of manganese neurotoxicity in humans: an update. Environ Res 73: 92-100

MOOS T, TRINDER D, MORGAN EH (2002) Effect of iron status on DMT1 expression in duodenal enterocytes from beta2-microglobulin knockout mice. Amer J Physiol 283: G687-694

MOOS T, MORGAN EH (2004) The significance of the mutated divalent metal transporter (DMT1) on iron transport into the Belgrade rat brain. J Neurochem 88: 233-245

MOROO I, UJIIE M, WALKER BL, TIONG JW, VITALIS TZ, KARKAN D, GABATHULER R, MOISE AR, JEFFERIES WA (2003) Identification of a novel route of iron transcytosis across the mammalian blood-brain barrier. Microcirculation 10: 457-462

NORMANDIN L, ANN BEAUPRE L, SALEHI F, STPIERRE A, KENNEDY G, MERGLER D, BUTTERWORTH RF, PHILIPPE S, ZAYED J (2004) Manganese distribution in the brain and neurobehavioral changes following inhalation exposure of rats to three chemical forms of manganese. Neurotoxicol 25: 433-441

OATES PS, THOMAS C, FREITAS E, CALLOW MJ, MORGAN EH (2000) Gene expression of divalent metal transporter 1 and transferrin receptor in duodenum of Belgrade rats. Am J Physiol 278: G930936

OBERDORSTER G, SHARP Z, ATUDOREI V, ELDER A, GELEIN R, KREYLING W, COX C (2004) Translocation of inhaled ultrafine particles to the brain. Inhal Toxicol 16: 437-445

OLANOW CW, GOOD PF, SHINOTOH H, HEWITT KA, VINGERHOETS F, SNOW BJ, BEAL MF, CALNE
DB, PERL DP (1996) Manganese intoxication in the rhesus monkey: A clinical, imaging, pathologic and biochemical study. Neurol 46: 492-498

PAL KP, SAMII A, CALNE DB (1999) Manganese neurotoxicity: A review of clinical features, imaging and pathology. Neurotoxicol 20: 227-238

PAPAVASILIOU PS, MILLER ST, COTZIAS, GC (1966) Role of liver in regulating distribution and excretion of manganese. Am J Physiol 211: 211-216

PASCAL LE, TESSIER DM (2004) Cytotoxicity of chromium and manganese to lung epithelial cells in vitro. Toxicol Lett 147: 143-151

PITYN P, CHAMBERLAIN MJ, FRASER TM, KING M, MORGAN WK (1989) The topography of particle deposition in the human lung. Respir Physiol 78: 19-29

PLENZ D, HERRERA-MARSCHITZ M, KITAI ST (1998) Morphological organization of the globus pallidussubthalamic nucleus system studied in organotypic cultures. J Comp Neurol 397: 437-457

RACETTE BA, MCGEE-MINNICH L, MOERLEIN SM, MINK JW, VIDEEN TO, PERLMUTTER JS (2001) Welding-related parkinsonism: Clinical features, treatment, and pathophysiology. Neurol 56: 8-13

RACETTE BA, ANTENOR JA, MCGEE-MINNICH L, MOERLEIN SM, VIDEEN TO, KOTAGAL V, PERLMUTTER JS (2005) [(18)F]FDOPA PET and clinical features in parkinsonism due to manganism. Mov Disord 20: 492-496

REIMUND JM, DIETEMANN JL, WARTER JM, BAUMANN R, DUCLOS B (2000) Factors associated to hypermanganesemia in patients receiving home parenteral nutrition. Clin Nutr 19: 343-348

ROELS H, LAUWERYS R, BUCHET JP, GENET P, SARHAN MJ, HANOTIAU I, DEFAYS M, BERNARD A, STANESCU D (1987) Epidemiological survey among workers exposed to manganese: Effects on lung, central nervous system, and some biological indices. Am J Ind Med 11: 307-327

RICCIO A, MATTEI C, KELSELL RE, MEDHURST AD, CALVER AR, RANDALL AD, DAVIS JB, BENHAM CD, PANGALOS MN (2002) Cloning and functional expression of human short TRP7, a candidate protein for store-operated $\mathrm{Ca} 2+$ influx. J Biol Chem 277: 12302-12309

ROTH JA, WALOWITZ J, BROWNE RW (2000) Manganese-induced rat pheochromocytoma (PC12) cell death is independent of caspase activation. J Neurosci Res 61: 162-171

ROTH JA, HORBINSKI C, HIGGINS D, LEIN P, GARRICK MD (2002) Mechanisms of manganeseinduced rat pheochromocytoma (PC12) cell death and cell differentiation. Neurotoxicol 23: 147-157

ROTH JA, GARRICK MD (2003) Iron interactions and other biological reactions mediating the physiological and toxic actions of manganese. Biochem Pharmacol 66: $1-13$

ROUSE ST, MARINO MJ, BRADLEY SR, AWAD H, WITTMANN M, CONN PJ (2000) Distribution and roles of metabotropic glutamate receptors in the basal ganglia motor circuit: Implications for treatment of Parkinson's disease and related disorders. Pharmacol Ther 88: 427-435

SCHRANTZ N, BLANCHARD DA, MITENNE F, AUFFREDOU MT, VÁZQUEZ A, LECA G (1999) Manganese induces apoptosis of human B cells: Caspase-dependent cell death blocked by Bcl-2. Cell Death Differen 6: 445-453

SCHROEDER HA, BALASSA JJ, TIPTON IH (1966) Essential trace metals in man: Manganese. A study in homeostasis. J Chron Dis 19: 545-571 
SPAHR L, BUTTERWORTH RF, FONTAINE S, BUI L, THERRIEN G, MILETTE PC, LEBRUN LH, ZAYED J, LEBLANC A, POMIER-LAYRARGUES G (1996) Increased blood manganese in cirrhotic patients: Relationship to pallidal magnetic resonance signal hyperintensity and neurological symptoms. Hepatol 24: 1116-1120

SUZUKI H, TAKANASHI J, SAEKI N, KOHNO Y (2003) Temporal parenteral nutrition in children causing t1 shortening in the anterior pituitary gland and globus pallidus Neuropediatrics 34: 200-204

SZIRAKI I, MOHANAKUMAR KP, RAUHALA, P, KIM HG, YEH KJ, CHIUEH, CC (1998) Manganese: A transition metal protects nigrostriatal neurons from oxidative stress in the iron-induced animal model of parkinsonism. Neurosci 85: 1101-1111

SZIRAKI I, RAUHALA P, CHIUEH CC (1995) Novel protective effect of manganese against ferrous citrateinduced lipid peroxidation and nigrostriatal neurodegeneration in vivo. Brain Res 698: 285-287

SZIRAKI I, RAUHALA P, KOH KK, VAN BERGEN P, CHIUEH CC (1999) Implications for atypical antioxidative properties of manganese in iron-induced brain lipid peroxidation and copper-dependent low density lipoprotein conjugation. Neurotoxicol 20: 455466

TAKEDA A, ISHIWATARI S, OKADA S (2000) Influence of transferrin on manganese uptake in rat brain, $\mathrm{J}$ Neurosci Res 59: 542-552

TALAVERA EJ, ARCAYA JL, GIRALDOTH D, SUÁREZ J, BONILLA E (1999) Decrease in spontaneous motor activity and in brain lipid peroxidation in manganese and melatonin treated mice. Neurochem Res 24: 705708

TJALVE H, HENRIKSSON J (1999) Uptake of metals in the brain via olfactory pathways. Neurotoxicol 120: 181-195

TRINDER D, OATES PS, THOMAS C, SADLEIR J, MORGAN EH (2000) Localisation of divalent metal transporter 1 (DMT1) to the microvillus membrane of rat duodenal enterocytes in iron deficiency, but to hepatocytes in iron overload. Gut 46: 270-276

VITARELLA D, WONG BA, MOSS OR, DORMAN DC (2000) Pharmacokinetics of inhaled manganese phosphate in male Sprague-Dawley rats following subacute (14-day) exposure. Toxicol Appl Pharmacol 163: $79-85$

WANG X, GHIO AJ, YANG F, DOLAN KG, GARRICK MD, PIANTADOSI CA (2002) Iron uptake and Nramp2/DMT1/DCT1 in human bronchial epithelial cells. Am J Physiol Lung Cell Mol Physiol 282: L987995

WESSELIUS LJ, WILLIAMS WL, BAILEY K, VAMOS S, OBRIEN-LADNER AR, WIEGMANN T (1999) Iron uptake promotes hyperoxic injury to alveolar macrophages. Am J Respir Crit Care Med 159: 100-106

WIDERA A, BELOUSSOW K, KIM KJ, CRANDALL ED, SHEN WC (2003a) Phenotype-dependent synthesis of transferrin receptor in rat alveolar epithelial cell monolayers. Cell Tissue Res 312: 313-318

WIDERA A, KIM KJ, CRANDALL ED, SHEN WC (2003b) Transcytosis of GCSF-transferrin across rat alveolar epithelial cell monolayers. Pharm Res 20: 1231-1238

WENLOCK RW, BUSS DH, DIXON EJ (1979) Trace nutrients. 2. Manganese in British food. Br J Nutr 41: 253-261

WRIGHT AK, ATHERTON JF, NORRIE L, ARBUTHNOTT GW (2004) Death of dopaminergic neurones in the rat substantia nigra can be induced by damage to globus pallidus. Eur J Neurosci 20: 1737-1744

World Health Organization, Manganese. Environmental Health Criteria, 17, Geneva, 1981

WU LJ, LEENDERS AG, COOPERMAN S, MEYRONHOLTZ E, SMITH S, LAND W, TSAI RY, BERGER UV, SHENG ZH, ROUAULT TA (2004) Expression of the iron transporter ferroportin in synaptic vesicles and the blood-brain barrier. Brain Res 1001: 108-117

YANG F, WANG X, HAILE DJ, PIANTADOSI CA, GHIO AJ (2002) Iron increases expression of iron-export protein MTP1 in lung cells, Am J Physiol Lung Cell Mol Physiol 283: L932-939

YOKEL RA, CROSSGROVE JS (2004) Manganese toxicokinetics at the blood-brain barrier. Res Rep Health Eff Inst 119: 7-58

YU IJ, KIM KJ, CHANG HK, SONG KS, HAN KT, HAN JH, MAENG SH, CHUNG YH, PARK SH, CHUNG KH, HAN JS, CHUNG HK (2000) Pattern of deposition of stainless steel welding fume particles inhaled into the respiratory systems of Sprague-Dawley rats exposed to a novel welding fume generating system. Toxicol Lett 116: 103-111

ZHENG W, ASCHNER M, GHERSI-EGEA JF (2003) Brain barrier systems: A new frontier in metal neurotoxicological research. Tox Appl Pharmacol 192: $1-11$

ZHANG S, FU J, ZHOU Z (2005) Changes in the brain mitochondrial proteome of male Sprague-Dawley rats treated with manganese chloride. Toxicol Appl Pharmacol 202: 13-17 